\title{
The Role of Culture in Foreign Direct Investment and Trade: Expectations from the GLOBE Dimensions of Culture
}

\author{
Raymond Mac-Dermott*, Dekuwmini Mornah \\ Virginia Military Institute, Lexington, VA, USA \\ Email: ${ }^{*}$ macdermottrj@vmi.edu
}

Received 22 December 2014; accepted 9 January 2015; published 20 January 2015

Copyright (C) 2015 by authors and Scientific Research Publishing Inc.

This work is licensed under the Creative Commons Attribution International License (CC BY).

http://creativecommons.org/licenses/by/4.0/

(c) (i) Open Access

\begin{abstract}
This paper offers qualitative analysis of the impact of culture on international business. In particular, we discuss the potential impact of each of the nine cultural dimensions that were established by the Global Leadership and Organizational Behavior Effectiveness Research Program, which is led by Robert J. House, on the decision to trade with or invest in another country. The analysis finds characterizations of source- and destination-country are important for each dimension when deciding between trade and FDI. Given the potentially conflicting recommendations, the dimensions are placed in a hierarchy to distinguish those most in need of consideration from those of secondary import.
\end{abstract}

\section{Keywords}

Culture, Trade, Foreign Direct Investment

\section{Introduction}

International business requires managers to evaluate the attractiveness and market potential of a country followed by the determination of the type and mode of entry. ${ }^{1}$ To determine the viability of the endeavor, managers will pore over data on demographics, economics, legal matters and more. Thoughtful managers would be wise to include a thorough analysis of culture as failure to properly do so will elevate the risk of failure.

*Corresponding author.

${ }^{1}$ The most prominent modes of entry include export, licensing, franchising, Greenfield ventures, mergers and acquisitions, and joint ventures. 
The value in understanding the effects of culture on business is not restricted to business managers. Policy makers, who initiate, negotiate, and enact agreements on trade and investment, would be wise to add culture to their calculus. Many policy makers recognize increases in foreign activity of multinational corporations are accompanied by increases in domestic activity [1]. At the same time, "foreign investors in the United States pay higher wages on average than US employers - even US multinationals, which are among the highest paying of all US firms" [2]. Thus policy makers recognize the benefits and encourage multinational activity, both at home and abroad, through policy. An understanding of culture and its ties to trade and investment would be valuable information for policy makers as they determine potential partner countries for international business.

It's obvious that culture matters when it comes to international business. And you would be hard-pressed to find anyone who believes otherwise as there is ample evidence demonstrating the link between culture and growth [3]-[5]. The devil, however, is in the details. Depending on the kind of business one is considering, some aspects of culture may promote or hinder international business prospects both in trade and foreign direct investments.

While some acknowledge the importance of culture in theory, they may find the notion of culture enigmatic and do not incorporate it into their analysis of international business. Others recognize its importance but simply search out partners culturally close to themselves, feeling that one can best do business with those like themselves. Some shrewd business leaders may see differences in culture as an opportunity to explore new markets and sell based on variety or produce based on a culture that is conducive for production. Essentially, differences in culture can be both a cost and an opportunity to international business.

Which aspects of culture promote international business and which aspects hinder it? How can an understanding of different aspects of culture guide businesses in choosing between investing in a foreign country or producing at home and trading with the foreign country? To have a better understanding of the effects of culture on international business prospects, a more sophisticated analysis is necessary and possible. The Global Leadership and Organizational Behavior Effectiveness Research Program (GLOBE) led by Robert J. House has developed nine dimensions to characterize a country's culture which can and should be incorporated into the analysis of any international business partner.

Several studies investigate the link between cultural distance and international business using an aggregate measure of Hofstede's four/six dimensions. These studies investigate trade [6]-[8] and foreign direct investment [9]-[11]. Other studies have used common language, religion or colonial history as proxies for culture [12] [13].

In this study, we offer insights on each of the nine GLOBE dimensions of culture on international business. Essentially, we analyze how each of the nine dimensions affect trade flows (exports) and foreign direct investment outflows (FDI).The analysis is made with the assumption that the business opportunity has already been identified and the choice is between trading (exports) and investing (FDI). Based on our analysis, we are able to help with the choice between investing in the country and trading in exports. We also suggest which aspects of culture are more influential on business.

The study extends, in three ways, the work of Head and Sorensen which used Hofstede's four dimensions to speculate as to which "cultural values might be attractive to businesses looking to engage in foreign direct investment" [14]. First, this study will discuss both trade and foreign direct investment and the substitutability or complementarity that may be culturally induced. Second, the discussion will be from both the source and recipient perspectives. Finally, it utilizes the nine dimensions of culture determined in the GLOBE study rather than Hofstede's four dimensions. ${ }^{2}$ As such, it should serve as a broad reference for managers and policy-makers involved in international business.

In the next section, we provide a brief theoretical link among culture, trade and investment. This is followed by a brief background of the GLOBE study, a description of each dimension as well as its expected link to trade and foreign direct investment. We close by offering a hierarchy of the cultural dimensions as they pertain to international business, and with concluding comments.

\section{Link between Culture, Trade and Investment}

For the purposes of this paper, we will focus on an examination of the effect of culture on the real side of inter-

${ }^{2}$ Hofstede's initial study included only four dimensions (Power Distance, Uncertainty Avoidance, Individualism-Collectivism, and Masculine-Feminine). Two more were added later (Long-term vs. Short-term Orientation and Indulgence vs. Restraint). 
national business, i.e. foreign direct investment (FDI) outflows or trade in goods and services(mainly exports). Generally, firms engage in international business either by investing and producing abroad or trading in homeproduced goods and services with foreign partners. Firms may invest in foreign countries for reasons of market access $^{3}$, cheaper production costs ${ }^{4}$ or a combination of both. Assuming economic conditions determine that it is profitable for a firm to do business with a foreign country, the firm can choose between exporting the final product or service to the destination country or establishing a presence in that country and producing the good or service locally.

Holding economic conditions constant, what will make a firm choose between trading in the final good with a foreign country and producing in the foreign country? Among other things, the target country's culture and how it affects business will be an important factor. Culture, or some aspects of culture, may be complementary to both trade (exports) and FDI (outflows). Other aspects of culture may induce some degree of substitutability between trade and FDI. When culture or some aspects of it is projected to be complementary to both trade and FDI, the decision to trade in goods with or invest in the foreign country is straightforward. That decision should be based mainly on the economic fundamentals. However, when culture or some aspects of it favor either trade or FDI, then the business decision calculus is not as straightforward. Depending on the aspect of culture that is being analyzed, either trade or FDI may be the more prudent option.

It is often assumed that investing in a foreign country carries greater risk than trading; especially when the countries are culturally different. The argument is usually made to the effect that all things being equal, investing in a foreign country comes with the added cost or risk of having to assimilate to the business and operational culture of that country. Failure to assimilate could spell doom for the investment project. But this is not always true because some differences in aspects of a country's culture may actually make it safer to invest in that country than at home. Just because they are different, they do not make them more dangerous. Generally, all things being equal, aspects of culture that make investments safer abroad, increase profitability, and rewards performance will attract FDI. On the other hand, when the economic opportunities exist but the culture is not favorable to FDI, trade will be preferred. In essence, the effect of culture on international business is not homogenous; it will depend on whether you are investing or trading. Our default position will be to trade rather than invest, all else equal, unless there exists a cultural incentive that will overcome the risk of investing. Therefore, given economic opportunities, if there is no culturally compelling reason to choose either of trade or foreign direct investment, we assume that the firm will default to trade.

\section{The GLOBE Culture Dimensions and International Business}

The last 30 years have seen great advances in quantifying culture. The works of Hofstede, the GLOBE team and European Values Survey/World Values Survey provide a wonderful foundation for studying the effects of cultural similarities or differences on economic behavior. ${ }^{5}$

Robert House led the Global Leadership and Organizational Behavior Effectiveness (GLOBE) study of crosscultural interactions. This on-going research program seeks to "increase available knowledge that is relevant to cross-cultural interactions" [15]. The data are a result of 17,000 questionnaires that are responded by managers from 951 organizations in telecommunications, food processing and finance across 62 cultures. This data was gathered between 1994 and 1997. The nine cultural dimensions that are identified as independent variables are Performance Orientation, Uncertainty Avoidance, Power Distance, Institutional Collectivism, In-Group Collectivism, Assertiveness, Future Orientation, Humane Orientation, and Gender Egalitarianism.

Since it was implemented more recently, ${ }^{6}$ and is more tailored toward business, having administered the survey to business managers across different industries and countries, our study will focus on the GLOBE dimensions of

${ }^{3}$ When firms invest abroad for reasons of market access, they mostly do so in order to circumvent transportation costs, jump tariffs and exploit destination markets.

${ }^{4}$ When firms invest abroad for reasons of production costs, they often do so to be closer to cheaper raw materials or technology and then re-export the final product or service to other markets.

${ }^{5}$ Though not our focus here, we would be remiss if we did not mention these two studies. Geert Hofstede administered 117,000 surveys across 72 countries while working for IBM in the 1970s. From this, he developed four dimensions of culture, later expanded to six. His work was the stepping stone for Robert House and the GLOBE team. The World Values Survey executed five waves of surveys in a total of 99 countries (the smallest sample was the first wave of 15 countries while the largest was the fourth of 70) over that last 30 years in the hopes of understanding changing values and their impact on social and political life. Empirical studies of the economic impact of culture draw on survey responses that quantify trust, respect, control and obedience.

${ }^{6}$ Hofstede’s work, for instance, was first published in 1980 while the GLOBE study was published in 2004. 
culture.

\subsection{Performance Orientation}

Performance Orientation $[\mathrm{ACH}]^{7}$ reflects "the extent to which a community encourages and rewards innovation, high standards, and performance improvement” [15]. High-ACH countries tend to "value education and learning, emphasize results, set high performance targets, value taking initiative, and prefer explicit and direct communication" [15]. Low-ACH countries associate competition with defeat and find assertiveness socially unacceptable.

It is safe to assume that multinational firms, by nature, seek out profit-making opportunities both at home and abroad; further, high performance standards are found to be positively correlated with productivity. ${ }^{8}$ As a result, firms from both high-ACH and low-ACH countries will find destination markets with high-Performance Orientation attractive for business. For firms from low-ACH countries, doing business with firms in high-ACH countries will help improve their efficiency, reduce costs and expose them to better work ethics. For firms from highACH countries, generally, they will be better served by seeking partners in similarly rated ACH countries. This is paramount because it reduces the potential of a collision of world-views. The fact that low-ACH countries find assertiveness to be socially unacceptable means that the probability of conflict between firms from very different ACH rated countries is high. This could potentially increase the costs of doing business such as arbitration costs and production in-efficiencies.

All else equal, we would expect a high-ACH score to be more attractive to international business. But firms have to choose between investing in production in the foreign country (FDI) or producing at home and exporting to the foreign country (trade). Due to the high standards and productivity associated with high-ACH countries, it is logical to say that firms would be better served by choosing investment over trade with those countries, all things being equal. But this prediction/suggestion may not hold uniformly across all countries; the greater the difference is in ACH ratings, the greater they gains to investment over trade. Firms originating from low-ACH countries should benefit more from investing in countries with higher-ACH ratings because of the significant efficiency improvements to be gained in production. On the other hand, when considering other low-ACH countries where efficiency gains are likely limited, the risk of investing abroad may not be justified. In this case, trade may be the better option because it comes with less risk than investing in a foreign country.

For firms originating from high-ACH countries, the efficiency gains from investing in another high-ACH country may not be sufficient to justify the risk of investing in abroad. This means for firms coming from countries with similarly-rated ACH levels, this cultural dimension alone cannot offer significant reasons to invest in one or the other. ${ }^{9}$ Again, trade may be the better option. Therefore, firms from higher-ACH countries should look to trade with firms in similar- or lower-ACH countries. In a nutshell, the degree of culturally-induced substitutability between trade and investment increases with increasing differences in $\mathrm{ACH}$ ratings and decreases with similar ACH ratings. This is summarized in Table 1.

Table 2 shows country rankings by each of the nine dimensions of culture as identified by the GLOBE team. ${ }^{10}$ Based on the table and our analysis, if ACH ratings alone were the deciding factor in choosing between trade or investment in order to take advantage of economic opportunities in another country, then we will expect that Switzerland, a high-ACH country, will prefer trade to investment with Singapore, another high-ACH country and Greece, a low-ACH country. On the other hand, Greece should prefer to invest in Switzerland while preferring to trade with Russia, a low-ACH country. But of course ACH ratings alone do not determine the decision to trade or invest. We may therefore need more sophisticated econometric analysis to tease out the partial effects.

\subsection{Uncertainty Avoidance}

Uncertainty Avoidance [UNC] refers to "the extent to which members of collectives seek orderliness, consis-

${ }^{7}$ For this and all dimensions, we use the abbreviations offered by GLOBE.

${ }_{8}$ According to the GLOBE study, societies that score high on Performance Orientation practices tend to be more economically prosperous and competitively successful.

${ }^{9}$ Note that there could be other compelling reasons to invest in countries with similar ACH ratings. The point being made here is that if we control the effect of all those other factors, then ACH ratings will not/should not be significant in explaining the flow of investment from one to the other.

${ }^{10}$ While we offer a rather unsophisticated, even split into high-, middle-, and low- categories, the GLOBE team uses more advances statistical techniques to cluster countries into upwards of five bands. 
Table 1. Performance Orientation.

\begin{tabular}{cccc}
\hline & & \multicolumn{2}{c}{ Destination } \\
\cline { 3 - 4 } & & High-ACH & Low-ACH \\
\hline \multirow{2}{*}{ Source } & High-ACH & Trade & Trade \\
& Low-ACH & Invest & Trade \\
\hline
\end{tabular}

Table 2. Country ranking by dimension.

\begin{tabular}{|c|c|c|c|c|c|c|c|c|c|}
\hline & $\begin{array}{c}\text { Performance } \\
\text { Orientation }\end{array}$ & $\begin{array}{l}\text { Uncertainty } \\
\text { Avoidance }\end{array}$ & $\begin{array}{c}\text { Power } \\
\text { Distance }\end{array}$ & $\begin{array}{l}\text { Institutional } \\
\text { Collectivism }\end{array}$ & $\begin{array}{c}\text { In-group } \\
\text { Collectivism }\end{array}$ & Assertiveness & $\begin{array}{c}\text { Future } \\
\text { Orientation }\end{array}$ & $\begin{array}{c}\text { Humane } \\
\text { Orientation }\end{array}$ & $\begin{array}{c}\text { Gender } \\
\text { Egalitarianism }\end{array}$ \\
\hline & {$[\mathrm{ACH}]$} & [UNC] & [POW] & [IND] & [TRI] & [AGG] & [FUT] & [HUM] & [MAL] \\
\hline \multirow{21}{*}{ 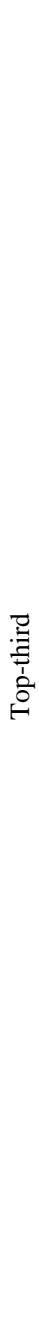 } & Switzerland & Switzerland & Morocco & Sweden & Philippines & Albania & Singapore & Zambia & Hungary \\
\hline & Singapore & Sweden & Nigeria & South Korea & Georgia & Nigeria & Switzerland & Philippines & Russia \\
\hline & Albania & Singapore & El Salvador & Japan & IRAN & Hungary & $\begin{array}{l}\text { S. Africa } \\
\text { (Black) }\end{array}$ & Ireland & Poland \\
\hline & Hong Kong & Denmark & Zimbabwe & Singapore & India & $\begin{array}{l}\text { Germany } \\
\text { (East) }\end{array}$ & Netherlands & Malaysia & Slovenia \\
\hline & New Zealand & $\begin{array}{l}\text { Germany } \\
\text { (West) }\end{array}$ & Argentina & New Zealand & Turkey & Hong Kong & Malaysia & Thailand & Denmark \\
\hline & $\begin{array}{l}\text { S. Africa } \\
\text { (Black) }\end{array}$ & Austria & Thailand & Denmark & Morocco & Austria & Austria & Egypt & Namibia \\
\hline & IRAN & $\begin{array}{l}\text { Germany } \\
\text { (East) }\end{array}$ & South Korea & China & Zambia & El Salvador & Denmark & Indonesia & Kazakhstan \\
\hline & Taiwan & Finland & Guatemala & Philippines & Ecuador & $\begin{array}{l}\text { S. Africa } \\
\text { (White) }\end{array}$ & Canada & Ecuador & Sweden \\
\hline & South Korea & Fr. Switzerland & Ecuador & Finland & China & Greece & Sweden & Albania & $\begin{array}{c}\text { Czech } \\
\text { Republic }\end{array}$ \\
\hline & Canada & China & Turkey & Ireland & Kuwait & $\begin{array}{l}\text { Germany } \\
\text { (West) }\end{array}$ & Japan & India & Albania \\
\hline & USA & Malaysia & Colombia & $\begin{array}{l}\text { S. Africa } \\
\text { (White) }\end{array}$ & Albania & USA & England & Kuwait & Canada \\
\hline & Philippines & New Zealand & Hungary & Zambia & Colombia & Turkey & $\begin{array}{c}\text { Fr. } \\
\text { Switzerland }\end{array}$ & Canada & Singapore \\
\hline & China & Netherlands & $\begin{array}{l}\text { Germany } \\
\text { (East) }\end{array}$ & Malaysia & Mexico & Morocco & $\begin{array}{l}\text { Germany } \\
\text { (West) }\end{array}$ & Zimbabwe & Colombia \\
\hline & Austria & England & Russia & Taiwan & Thailand & Switzerland & Finland & Denmark & England \\
\hline & Indonesia & $\begin{array}{l}\text { S. Africa } \\
\text { (Black) }\end{array}$ & Spain & Indonesia & Indonesia & Kazakhstan & India & Qatar & Portugal \\
\hline & Australia & Canada & India & Albania & Egypt & Mexico & Philippines & Costa Rica & $\begin{array}{l}\text { S. Africa } \\
\text { (Black) }\end{array}$ \\
\hline & Ireland & Albania & Philippines & Poland & Singapore & Spain & USA & China & Philippines \\
\hline & Malaysia & $\begin{array}{c}\text { Czech } \\
\text { Republic }\end{array}$ & Portugal & Qatar & Guatemala & South Korea & $\begin{array}{l}\text { S. Africa } \\
\text { (White) }\end{array}$ & $\begin{array}{l}\text { S. Africa } \\
\text { (Black) }\end{array}$ & France \\
\hline & Netherlands & France & IRAN & Russia & Russia & $\begin{array}{l}\text { S. Africa } \\
\text { (Black) }\end{array}$ & Nigeria & New Zealand & Mexico \\
\hline & Egypt & Australia & Italy & Egypt & Taiwan & Venezuela & Australia & Japan & Qatar \\
\hline & Fr. Switzerland & Taiwan & Greece & Kuwait & Zimbabwe & Netherlands & Hong Kong & Australia & Venezuela \\
\hline \multirow{5}{*}{ 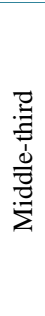 } & $\begin{array}{l}\text { Germany } \\
\text { (West) }\end{array}$ & Hong Kong & Venezuela & Netherlands & Nigeria & Australia & Ireland & Venezuela & Costa Rica \\
\hline & India & Ireland & Slovenia & Israel & South Korea & Israel & South Korea & IRAN & Georgia \\
\hline & Zimbabwe & Nigeria & Brazil & $\begin{array}{l}\text { S. Africa } \\
\text { (Black) }\end{array}$ & Venezuela & Argentina & Taiwan & Morocco & Bolivia \\
\hline & Denmark & Kuwait & Zambia & India & Poland & Brazil & $\begin{array}{l}\text { Germany } \\
\text { (East) }\end{array}$ & Georgia & Malaysia \\
\hline & Japan & Namibia & Kazakhstan & Canada & Portugal & Colombia & Mexico & $\begin{array}{c}\text { Czech } \\
\text { Republic }\end{array}$ & Netherlands \\
\hline
\end{tabular}




\section{Continued}

\begin{tabular}{|c|c|c|c|c|c|c|c|c|c|}
\hline \multirow{15}{*}{ 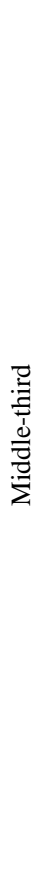 } & Ecuador & Mexico & Namibia & Austria & Malaysia & Georgia & Egypt & USA & Argentina \\
\hline & Zambia & Indonesia & France & Kazakhstan & Argentina & Singapore & Indonesia & Taiwan & Greece \\
\hline & Costa Rica & Zimbabwe & $\begin{array}{l}\text { Germany } \\
\text { (West) }\end{array}$ & Australia & Bolivia & England & Albania & Sweden & Hong Kong \\
\hline & $\begin{array}{l}\text { S. Africa } \\
\text { (White) }\end{array}$ & India & Mexico & England & Spain & France & Israel & Nigeria & $\begin{array}{c}\text { Fr. } \\
\text { Switzerland }\end{array}$ \\
\hline & Czech Republic & USA & Georgia & Fr. Switzerland & Slovenia & Qatar & Brazil & Israel & Australia \\
\hline & France & Zambia & Taiwan & USA & El Salvador & Ecuador & El Salvador & Bolivia & Finland \\
\hline & Mexico & $\begin{array}{l}\text { S. Africa } \\
\text { (White) }\end{array}$ & Indonesia & Nigeria & Costa Rica & Zambia & Qatar & Kazakhstan & Thailand \\
\hline & Germany (East) & Japan & Malaysia & Namibia & Hong Kong & Italy & Zimbabwe & Argentina & USA \\
\hline & England & Egypt & $\begin{array}{l}\text { S. Africa } \\
\text { (White) }\end{array}$ & Slovenia & Greece & Zimbabwe & China & Mexico & Brazil \\
\hline & Israel & Israel & England & Hong Kong & Kazakhstan & Poland & Turkey & Finland & $\begin{array}{l}\text { S. Africa } \\
\text { (White) }\end{array}$ \\
\hline & Brazil & Qatar & Ireland & Zimbabwe & Hungary & Canada & Ecuador & Namibia & Indonesia \\
\hline & Spain & Spain & Kuwait & Switzerland & Brazil & IRAN & Portugal & Turkey & Italy \\
\hline & Morocco & Thailand & Japan & Mexico & Ireland & Philippines & IRAN & Russia & New Zealand \\
\hline & Kuwait & Portugal & Poland & Bolivia & $\begin{array}{l}\text { S. Africa } \\
\text { (Black) }\end{array}$ & Slovenia & $\begin{array}{c}\text { Czech } \\
\text { Republic }\end{array}$ & $\begin{array}{c}\text { Fr. } \\
\text { Switzerland }\end{array}$ & Ireland \\
\hline & Colombia & Philippines & China & Turkey & Italy & Ireland & Zambia & Portugal & Japan \\
\hline \multirow{21}{*}{ 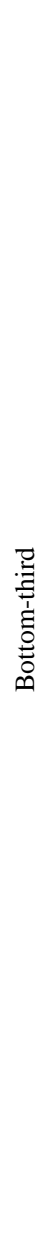 } & Thailand & Costa Rica & Singapore & Georgia & Austria & Taiwan & Bolivia & Hong Kong & Israel \\
\hline & Nigeria & Italy & Hong Kong & Thailand & Qatar & Namibia & Costa Rica & Guatemala & Taiwan \\
\hline & Poland & Slovenia & Austria & Venezuela & Israel & Egypt & Slovenia & Netherlands & El Salvador \\
\hline & Georgia & Ecuador & Egypt & Costa Rica & Japan & Guatemala & Kazakhstan & South Korea & $\begin{array}{l}\text { Germany } \\
\text { (West) }\end{array}$ \\
\hline & Turkey & IRAN & Switzerland & France & $\begin{array}{l}\text { Germany } \\
\text { (East) }\end{array}$ & Malaysia & Spain & Slovenia & Austria \\
\hline & Finland & Kazakhstan & Finland & Portugal & Namibia & Indonesia & Namibia & Austria & Ecuador \\
\hline & Guatemala & Morocco & New Zealand & Ecuador & $\begin{array}{l}\text { S. Africa } \\
\text { (White) }\end{array}$ & Finland & France & Colombia & $\begin{array}{l}\text { Germany } \\
\text { (East) }\end{array}$ \\
\hline & Sweden & Argentina & USA & IRAN & France & Denmark & New Zealand & England & China \\
\hline & El Salvador & Turkey & $\begin{array}{c}\text { Fr. } \\
\text { Switzerland }\end{array}$ & Morocco & Canada & Bolivia & Thailand & El Salvador & Zimbabwe \\
\hline & Namibia & Poland & Sweden & Spain & USA & China & Georgia & Brazil & Guatemala \\
\hline & Slovenia & El Salvador & Canada & Brazil & Australia & Costa Rica & Greece & Italy & Nigeria \\
\hline & Argentina & Brazil & Australia & Colombia & England & India & Venezuela & Poland & Spain \\
\hline & Bolivia & Colombia & Costa Rica & $\begin{array}{l}\text { Germany } \\
\text { (West) }\end{array}$ & Finland & $\begin{array}{c}\text { Czech } \\
\text { Republic }\end{array}$ & Colombia & Switzerland & IRAN \\
\hline & Portugal & South Korea & Qatar & El Salvador & $\begin{array}{l}\text { Germany } \\
\text { (West) }\end{array}$ & Russia & Kuwait & $\begin{array}{l}\text { S. Africa } \\
\text { (White) }\end{array}$ & Switzerland \\
\hline & Italy & Georgia & Israel & Guatemala & Switzerland & Portugal & Morocco & Singapore & India \\
\hline & Kazakhstan & Venezuela & Albania & Italy & $\begin{array}{c}\text { Fr. } \\
\text { Switzerland }\end{array}$ & Thailand & Italy & $\begin{array}{l}\text { Germany } \\
\text { (East) }\end{array}$ & Turkey \\
\hline & Qatar & Greece & Bolivia & Argentina & Netherlands & Kuwait & Guatemala & France & Zambia \\
\hline & Hungary & Bolivia & Netherlands & Czech Republic & New Zealand & Japan & Hungary & Hungary & Morocco \\
\hline & Russia & Guatemala & $\begin{array}{l}\text { S. Africa } \\
\text { (Black) }\end{array}$ & Germany (East) & Sweden & $\begin{array}{c}\text { Fr. } \\
\text { Switzerland }\end{array}$ & Poland & Greece & Egypt \\
\hline & Venezuela & Hungary & Denmark & Hungary & Denmark & New Zealand & Argentina & Spain & Kuwait \\
\hline & Greece & Russia & $\begin{array}{c}\text { Czech } \\
\text { Republic }\end{array}$ & Greece & $\begin{array}{c}\text { Czech } \\
\text { Republic }\end{array}$ & Sweden & Russia & $\begin{array}{l}\text { Germany } \\
\text { (West) }\end{array}$ & South Korea \\
\hline
\end{tabular}


tency, structure, formalized procedures, and laws to cover situations in their daily lives” [15]. ${ }^{11}$ In high-UNC countries, firms tend to engage in formal interactions including legal contracts and meticulous record-keeping. Further, they would be much more calculating when taking risk and more resistant to change. Ideally, firms want more certainty about their business operations. Therefore, countries with high-UNC will be good candidates to do business with provided you are able to find willing partners.

For this dimension, managers would undoubtedly seek those like themselves. Those from a high-UNC country, where order and structure are paramount, would be uncomfortable with low-UNC destinations where informality is more common. In this case, trade would be the better approach to market penetration. These same managers would likely find other high-UNC countries, who entertain a similar mindset with respect to procedure, attractive for investment. Similarly, managers from low-UNC countries would find investing in other low-UNC countries appealing but disagreeable when considering high-UNC destinations. This is depicted in Table 3.

Going back to Table 2 for real life comparisons, based on UNC ratings alone, firms from high-UNC countries such as Switzerland, Sweden and Singapore should be comfortable investing in each other while choosing to trade with Russia, Hungary or Guatemala - the lowest rated UNC countries. Similarly, these low-UNC countries will find success investing among their own while choosing to trade with Switzerland, Sweden and Singapore, all things being equal.

\subsection{Power Distance}

Power Distance $[\mathrm{POW}]$ reflects "the degree to which members of an organization or society expect and agree that power should be shared unequally" [15]. In high-POW countries, there is a clear hierarchy or chain of command. For a firm to feel comfortable sourcing a portion of their production process abroad, they must feel comfortable with their ability to control these activities.

Given the similarities in decision-making and power structure, firms in high-POW countries should feel at ease investing in other high-POW countries where there is a clear chain of command and individuals are more easily held accountable. These same firms would feel uncomfortable investing in low-POW countries where the decision-making structure is much flatter. In the case of business relations with firms from low-POW countries, the firms originating from high-POW countries will be better served by trading with those from low-POW countries rather than investing.

Firms coming from high-POW countries will likely seek to invest with people more like them and trade with people different from them. What about firms originating from low-POW countries? The same thinking applies. We would expect firms from these countries to invest in other low-POW countries and trade with high-POW countries. The reasoning is that firms from low-POW countries are used to a more collegial work environment where the hierarchy is flatter. As seen in Table 4, they will prefer to invest in countries that think more like themselves in order to avoid frictions with those who are different. Consequently, given that an economic opportunity has been found in a partner country, firms from low-POW countries will be more inclined to invest in those more like them and trade with those different from them.

Table 3. Uncertainty Avoidance.

\begin{tabular}{cccc}
\hline & & & Destination \\
\cline { 3 - 3 } & & High-UNC & Low-UNC \\
\cline { 3 - 3 } Source & High-UNC & Invest & Trade \\
& Low-UNC & Trade & Invest \\
\hline
\end{tabular}

\section{Table 4. Power Distance.}

\begin{tabular}{cccc}
\hline & & & Destination \\
& & High-POW & Low-POW \\
\hline \multirow{2}{*}{ Source } & High-POW & Invest & Trade \\
& Low-POW & Trade & Invest \\
\hline
\end{tabular}

${ }^{11}$ Note- - Uncertainty Avoidance is not synonymous with risk avoidance. (Hofstede draws this distinction while GLOBE only makes reference to his work). 
Based on this dimension alone, high-POW countries, such as Morocco, Nigeria and El Salvador should be comfortable investing in each other while choosing trade with low-POW countries such as South Africa, Denmark and the Czech Republic. Similarly, these low-POW countries should be looking to investing with each other while choosing to trade with the likes of Morocco, Nigeria and El Salvador.

\subsection{Individualism-Collectivism}

While Individualism vs. Collectivism has been studied in the past [16] [17] the GLOBE team believed this simple distinction aggregated distinct elements; thus the development of two related dimensions: In-Group Collectivism [TRI] and Institutional Collectivism [IND]. In-Group Collectivism "specifically measured whether children take pride in the individual accomplishments of their parents and vice versa, whether aging parents live at home with their children, and whether children live at home with their parents until they get married” [15]. While this is an interesting dimension of culture, it is likely of little value to business managers when deciding between trade and investment. Table 5 and Table 6, respectively, demonstrate the effect of In-group and Institutional Collectivism.

Institutional Collectivism [IND] reflects the degree to which institutional practices at the societal level encourage and reward collective action. High-IND countries are more collectivist. Employees tend to develop long-term relationships with employers and make personal sacrifices to fulfill organizational obligations. If one can regard foreign direct investment as a group activity, these attributes are certainly attractive to potential investors. In addition, firms appreciate loyal employees, as they limit costly turnover, and the fact that everybody is involved creates a sense of ownership and that will boost worker performance more than in cases where there is more individualism and no sense of ownership of the process.

It should be noted that, in these collectivist societies, important decisions are made by groups. Group action is more costly than individual action because of the higher transaction costs involved in coming to group decisions. However, the preponderance of the evidence suggests that, even with the potential drag to decision-making, firms of all types would benefit from investing in collectivist societies. In more individualist societies, firms would likely be better off through trade.

When looking to Institutional Collectivism, the decision to trade or invest is not dependent upon the source country. If the destination country is high-IND or more collectivist, such as Sweden or Japan, business managers would be attracted to the loyalty demonstrated by workers. As such, investment is the recommended approach, regardless of the Collectivist/Individualist proclivities of the source country. If the target country is more Individualist, such as Hungary or Greece, then trade should carry the day.

\subsection{Assertiveness}

Assertiveness [AGG] is defined as "the degree to which individuals in organizations or societies are assertive, tough, dominant, and aggressive in social relationships” [15]. In general, societies that score higher on Assertiveness tend to reward performance and value competition, success and direct communication while less assertive countries value cooperation and equality.

Table 5. In-Group Collectivism.

\begin{tabular}{cccc}
\hline & & \multicolumn{2}{c}{ Destination } \\
\cline { 3 - 4 } & & High-TRI & Low-TRI \\
\hline \multirow{2}{*}{ Source } & High-TRI & Trade & Trade \\
& Low-TRI & Trade & Trade \\
\hline
\end{tabular}

Table 6. Institutional Collectivism.

\begin{tabular}{cccc}
\hline & & Destination & \\
Low-IND & High-IND & Trade \\
\cline { 3 - 4 } Source & & Invest & Trade \\
\hline
\end{tabular}


High-Assertiveness seems to be a trait that businesses will embrace because it breeds efficiency and transparency in business operations. High-AGG countries value competition and taking initiative and should therefore drive firms to seek and exploit opportunities in foreign markets. There is not a dominant strategy however between investing and trading because the choice will depend on the assertiveness level of the partner.

All things being equal, countries of similar Assertiveness levels should have similar productivity levels. Therefore, there can be no cultural justification based on AGG to take the added risk of investment in a foreign country; trade is the better approach.

On the other hand, when comparing two countries of dissimilar rank, investing may be a possibility. Firms in low-AGG countries may want to invest in countries with high-AGG ratings as they may benefit from the associated production efficiency. As discussed earlier, such productivity gains for firms from low-AGG countries investing in high-AGG countries will be non-existent if the investments were to be made in other low-AGG countries. This means that in the presence of economic opportunities, holding all things constant, then firms from low-AGG countries should trade with other low-AGG countries while seeking to invest with higher-AGG countries.

Finally, one will expect more trade flows (exports) from the high-AGG country to the low-AGG country for two reasons. First, there will be little competition in the low-AGG country thus leaving room for high profit margins. And second, low-AGG countries are not as competitive as their high-AGG counterparts so investing in such countries could compromise productivity. This is depicted in Table 7.

On Assertiveness, Albania, Nigeria and Hungary—the high-AGG countries—should trade more with each other and also with French Switzerland, New Zealand or Sweden-the low-AGG countries. However, all things being equal, French Switzerland, New Zealand or Sweden should look to invest in Albania, Nigeria and Hungary while trading more with other low-AGG countries.

\subsection{Future Orientation}

Future Orientation [FUT] reflects "the extent to which members of a society or an organization believe that their current actions will influence their future, focus on investment in their future, believe that they will have a future that matters, believe in planning for developing their future, and look far into the future for assessing the effects of their current actions" [15]. High-FUT cultures have a propensity to save for the future, have more intrinsically motivated individuals and achieve greater economic success. Their organizations have longer strategic orientations and are more adaptable. Low-FUT countries, on the other hand, place higher priorities on immediate rewards and take a shorter strategic view. The clear and contrasting differences between high-FUT and low-FUT countries will have obvious consequences on the decision to invest or trade with a partner given economic opportunity and the Future Orientation of the partners. Given the association with greater economic success, we would expect firms from high-FUT countries to actively seek export and investment opportunities with foreign countries.

The characterization of high-Future Oriented countries seems to mimic those of the mercantilists-maximize exports and minimize imports. So even though an opportunity may exist in a high-FUT country, their actions, explicit or implicit, will tend to limit imports from other countries. Because imports are unwelcome in a high-FUT country, the source country, which is high- or low-FUT, would be best served through investment. On the other hand, when the destination country is low-FUT, trade is the better approach for two reasons. First, we would expect trade opportunities to abound as the destination country is non-mercantilist. Second, the lack of intrinsic motivation associated with low-FUT countries would fail to justify the risk of investing. This is summamarized in Table 8.

Regardless of the source country, target markets in high-FUT countries, such as Singapore, Switzerland, or

Table 7. Assertiveness.

\begin{tabular}{cccc}
\hline & & \multicolumn{2}{c}{ Destination } \\
\cline { 3 - 4 } & & High-AGG & Low-AGG \\
\hline \multirow{2}{*}{ Source } & High-AGG & Trade & Trade \\
& Low-AGG & Invest & Trade \\
\hline
\end{tabular}


Table 8. Future Orientation.

\begin{tabular}{cccc}
\hline & & \multicolumn{2}{c}{ Destination } \\
\cline { 3 - 4 } & & High-FUT & Low-FUT \\
\hline \multirow{2}{*}{ Source } & High-FUT & Invest & Trade \\
& Low-FUT & Invest & Trade \\
\hline
\end{tabular}

the Netherlands, should be better served by investing. At the same time, low-FUT markets, such as Poland, Argentina and Russia, should be reached through trade.

\subsection{Humane Orientation}

Humane Orientation [HUM] is defined as "the degree to which an organization or society encourages and rewards individuals for being fair, altruistic, friendly, generous, caring, and kind to others. This dimension is manifested itself in the way people treat one another and in the social programs institutionalized within each society" [15]. In high-HUM cultures, we would expect to find individuals (and organizations) that are more fair and kind. For firms in low-HUM countries, this beneficial environment would likely encourage investment. This is so because they will believe that their investments will be safe and treated fairly-something that they will not have in their originating low-HUM country. For high-HUM firms, who come from a similar landscape, there will be little to no additional benefits to reap from investing in other high-HUM countries. On the other hand, both lowand high-HUM countries would likely be put off by the less hospitable environment found in low-HUM countries. All things being equal, it will make no sense for firms from high-HUM countries to leave more investment to favorable environments than to less favorable environments while those firms originating from low-HUM countries will have no added benefit to moving to other low-HUM countries. Therefore, these firms (originating from both high- and low-HUM countries) would likely default to trade for international business with low-HUM countries. This is summarized in Table 9 .

When the choice of market penetration mode is based on Humane Orientation, high-HUM countries such as Zambia, Philippines and Ireland should choose trade both with other high-HUM countries as well as low-HUM countries such as Greece, Spain and Germany. These low-HUM countries would be better served by choosing investment with the high-HUM countries while trading with each other.

\subsection{Gender Egalitarianism}

Gender Egalitarianism [MAL] reflects "the ways in which societies divide roles between women and men. The more gender egalitarian a society is, the less it relies on biology to determine women's and men's social roles" [15]. Societies with high-MAL scores tend to have similar levels of education for men and women and more women in positions of authority. When roles are not restricted, it may imply that more opportunities to trade and invest exist. While Gender Egalitarianism is an interesting and important dimension of culture, when it comes to choosing between trade and investment, it does not appear to inform firm decisions. In other words, Gender Egalitarianism fails to offer additional incentive to invest that would override the inherent risk.

In practice, MAL ratings do not seem to have compelling reasons to ever choose investment irrespective of the MAL levels of the partner country. Therefore, as demonstrated in Table 10, trade is the dominant strategy irrespective of the HUM levels.

\section{Which Is More Important? Rankings the Dimensions}

Several factors definitely affect the investment-trade decision in international business not only limited to economic factors. Political factors as well as cultural factors will be significant determinants in that choice. In the previous section, we analyzed how each cultural dimension is likely to influence the choice between trade and investment given an economic opportunity exists with a partner country. Some of the recommendations are contradictory as to investing or trading based on the dimension being analyzed.

For instance, Switzerland, a high-Performance Orientation country, should trade with other high-ACH countries such as Singapore. However, when looking at Future Orientation, Switzerland, a high-FUT country, should 
Table 9. Humane Orientation.

\begin{tabular}{cccc}
\hline & & Destination \\
\cline { 3 - 4 } & & High-HUM & Low-HUM \\
\cline { 3 - 4 } Source & High-HUM & Trade & Trade \\
& Low-HUM & Invest & Trade \\
\hline
\end{tabular}

Table 10. Gender Egalitarianism.

\begin{tabular}{cccc} 
& & & Destination \\
\cline { 3 - 4 } & & High-MAL & Low-MAL \\
\hline \multirow{2}{*}{ Source } & High-MAL & Trade & Trade \\
& Low-MAL & Trade & Trade \\
\hline
\end{tabular}

invest in other high-FUT countries such as Singapore. Clearly, the two dimensions offer contradictory guidance. If the two are in conflict, does one take precedence? Are there practical reasons to value one cultural dimension more than the other?

The answer to the above questions is not a simple one as it will depend on the countries involved, the kind of business opportunity that exists and other economic and political factors. Fundamentally, the question of which cultural dimension is important is one of preference. However, all else equal, the impact of some dimensions should be more compelling than others.

It is the nature of culture that makes it important; it is ingrained in the moral fabric of the society. But some aspects of culture are more ingrained while others are more amenable. In deciding which dimensions of culture are important for business, the relevant dimensions should be those that directly aid productivity and those that cannot be changed. For instance, if a dimension aids productivity and at the same time is less amenable to change, then that dimension should be ranked higher. Based on this rubric, we identify four categories of culture based on importance found in Table 11.

In our view, Performance Orientation should carry more weight among the cultural dimensions. Performance Orientation has more direct effect on productivity and more ingrained because changing the mindset has to be a social effort which can take quite some time.

The next tier includes Uncertainty Avoidance and Power Distance. Based upon our earlier analysis, each of these clearly has an effect on productivity and is not easily changed, though perhaps not quite as rigid as Performance Orientation. As a result, the firm should give strong consideration to whether the two dimensions are compatible with its operations.

While Future Orientation, Institutional Collectivism and Assertiveness are important for business each appears more amenable. For instance, Future Oriented countries save more and spend less. They tend to want to export more and import less. However, because of the multiplicity of international organizations such as the WTO, regional trade agreements, and bilateral trade and investment treaties, the policy options available to countries to advance their anti-import policies will be limited. Institutional Collectivism and Assertiveness are qualities that we believe can be honed at the work place. Depending on the work culture of the organization, they can put incentives in place to move towards the desired Institutional Collectivism or Assertiveness levels.

Finally, Gender Egalitarianism, Humane Orientation and In-group Collectivism are at the bottom of our pyramid. These dimensions, while important elements of a culture, do not seem to be more inclined to business. There is no evidence to show that more egalitarian societies are more productive or vice versa. Humane Orientation and In-group Collectivism are dimensions that can be refined at the work place with appropriate incentives if they are found important by the particular organization.

\section{Conclusions}

The purpose of this study was to introduce readers to the Global Leadership and Organizational Behavior Effectiveness Research Program (GLOBE) and the notion of culture is, in fact, quantifiable. We then reviewed each of the nine dimensions of culture and offered insights into the expected relationship between each dimension and both trade and foreign direct investment. It is our hope that both international business managers and policy 
Table 11. Hierarchy of dimensions.

\begin{tabular}{|c|c|c|c|}
\hline \multicolumn{2}{|c|}{ Most Important------ } & \multicolumn{2}{|c|}{-----Least Important } \\
\hline Performance Orientation & $\begin{array}{c}\text { Power Distance } \\
\text { Uncertainty Avoidance }\end{array}$ & $\begin{array}{c}\text { Assertiveness } \\
\text { Future Orientation } \\
\text { Institutional Collectivism }\end{array}$ & $\begin{array}{c}\text { Gender Egalitarianism } \\
\text { Humane Orientation } \\
\text { In-group Collectivism }\end{array}$ \\
\hline
\end{tabular}

makers may benefit from this additional insight into culture.

We will end with two disclaimers. The first, even though culture is important, this study does not claim that culture is the only or even the main determinant of international business. The study is premised on the assumption that all things being equal, culture can and should be a significant explainer of the pattern of international business. Our analysis show that different aspects of culture have different effects on business and the decision to trade or invest. The perfect country is not the one that scores high in all dimensions as high scores in some dimensions may be anti-business or business-friendly depending on the partner with whom you are dealing.

The second is to acknowledge the need for more analysis. This qualitative analysis should serve as only the first step into this discussion. Given the availability of cultural metrics, a larger research project can and should empirically investigate the effects of each cultural dimension on trade and investment.

\section{References}

[1] Hufbauer, G.C., Moran, T.H., Oldenski, L. and Vieiro, M. (2013) Outward Foreign Direct Investment and US Exports, Jobs, and R\&D: Implications for US Policy. Peterson Institute for International Economics, Washington DC.

[2] Moran, T.H. and Oldenski, L. (2013) Foreign Direct Investment in the United States: Benefits, Suspicions, and Risks with Special Attention to FDI from China. Peterson Institute for International Economics, Washington DC.

[3] Barro, R.J. and McCleary, R. (2003) Religions and Economic Growth. The National Bureau of Economic Research, Working Paper No. 9682.

[4] Tabellini, G. (2010) Culture and Institutions: Economic Development in the Regions of Europe. Journal of the European Economic Association, 8, 677-716. http://dx.doi.org/10.1111/j.1542-4774.2010.tb00537.x

[5] Easterly, W. (2006) Social Cohesion, Institutions and Growth. Center for Global Development, Working Paper No. 94.

[6] Linders, G., Slangen, A., de Groot, H. and Beugelsdijk, S. (2005) Cultural and Institutional Determinants of Bilateral Trade Flows. Tinbergen Institute Discussion Paper, TI 2005-074/3.

[7] Tadesse, B. and White, R. (2007) Cultural Distance as a Determinant of Bilateral Trade Flows: Do Immigrants Counter the Effect of Cultural Differences? Applied Economic Letters, 17, 147-152. http://dx.doi.org/10.1080/13504850701719983

[8] Cyrus, T. (2012) Cultural Distance and Bilateral Trade. Global Economy Journal, 12.

[9] Kogut, B. and Singh, H. (1988) The Effect of National Culture on the Choice of Entry Mode. Journal of International Business Studies, 19, 411-432. http://dx.doi.org/10.1057/palgrave.jibs.8490394

[10] Benito, G. and Gripsrud, G. (1992) The Expansion of Foreign Direct Investments: Discrete Rational Location Choices or a Cultural Learning Process? Journal of International Business Studies, 23, 461-476. http://dx.doi.org/10.1057/palgrave.jibs.8490275

[11] Chakrabarti, R., Gupta-Mukherjee, S. and Jayaraman, N. (2009) Mars-Venus Marriages: Culture and Cross-Border M\&A. Journal of International Business Studies, 40, 216-236. http://dx.doi.org/10.1057/jibs.2008.58

[12] Eichengreen, B. and Irwin, D. (1998) The Role of History in Bilateral Trade Flows. In: Frankel, J.A., Ed., The Regionalization of the World Economy, University of Chicago Press, Chicago, 33-62.

[13] De Groot, H.L., Linders, G.J., Rietveld, P. and Subramanian, U. (2004) The Institutional Determinants of Bilateral Trade Patterns. Kyklos, 57, 103-123. http://dx.doi.org/10.1111/j.0023-5962.2004.00245.x

[14] Head, T. and Sorensen, P. (2005) Attracting Foreign Direct Investment: The Potential Role of National Culture. Journal of American Academy of Business, 6, 305-308.

[15] House, R.J., Hanges, P.J., Javidan, M., Dorfman, P.W. and Gupta, V. (2004) Culture, Leadership and Organizations: The GLOBE Study of 62 Societies. Sage Publications, Thousand Oaks.

[16] Hofstede, G. (2001) Culture’s Consequences. Sage Publications, Thousand Oaks.

[17] Triandis, H.C. (1995) Individualism and Collectivism. Westview Press, Boulder. 
Scientific Research Publishing (SCIRP) is one of the largest Open Access journal publishers. It is currently publishing more than 200 open access, online, peer-reviewed journals covering a wide range of academic disciplines. SCIRP serves the worldwide academic communities and contributes to the progress and application of science with its publication.

Other selected journals from SCIRP are listed as below. Submit your manuscript to us via either submit@scirp.org or Online Submission Portal.
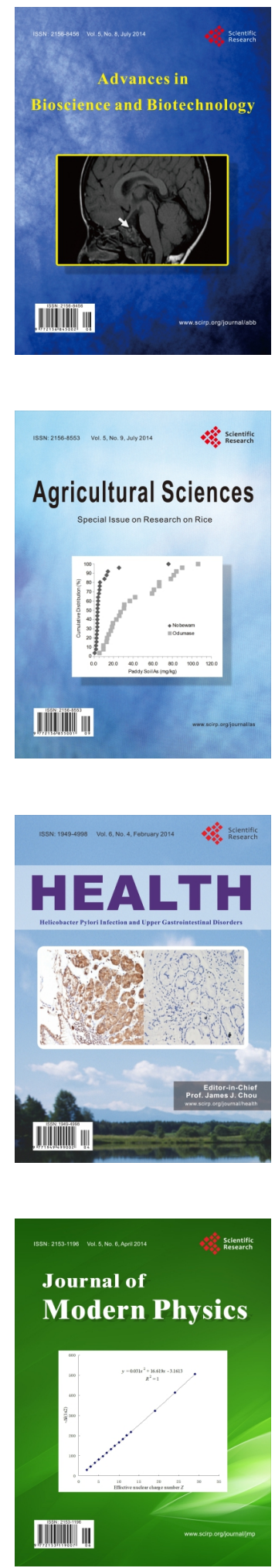
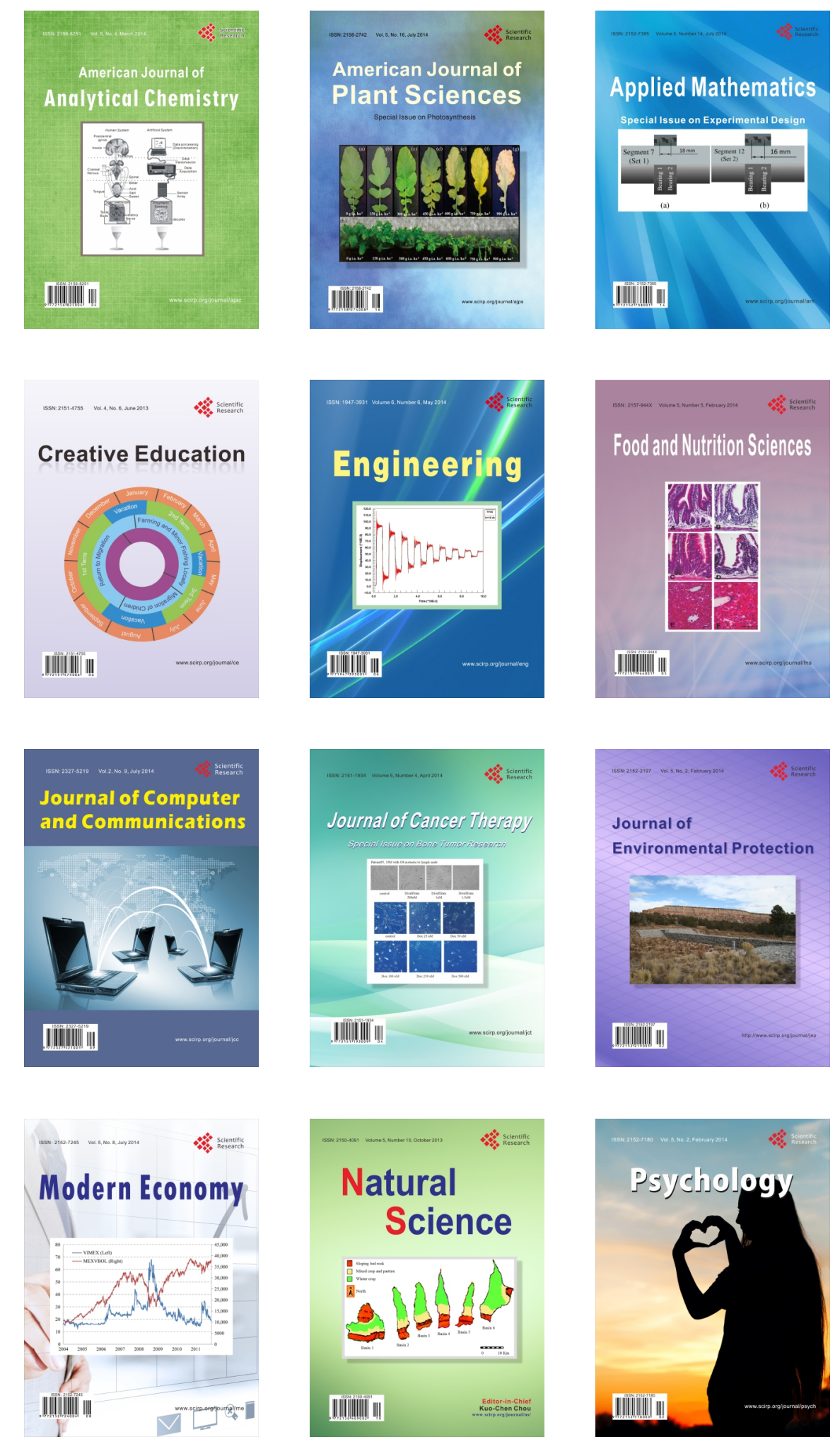